CZASOPISMO INŻYNIERII LĄDOWEJ, ŚRODOWISKA I ARCHITEKTURY JOURNAL OF CIVIL ENGINEERING, ENVIRONMENT AND ARCHITECTURE

JCEEA, t. XXXIII, z. 63 (4/16), październik-grudzień 2016, s. 159-168

Marek GOSZTYŁA ${ }^{1}$

Lukasz GOŁDA ${ }^{2}$

\title{
PROBLEMATYKA BUDOWLANO-KONSERWATORSKA ZABYTKOWYCH OBIEKTÓW KONSTRUKCJI DREWNIANYCH NA PRZYKŁADZIE KOŚCIOŁA PW. ŚW. MIKOŁAJA BISKUPA W DOMARADZU
}

\begin{abstract}
Problematyka prowadzenia prac rewaloryzacyjnych drewnianych obiektów zabytkowych zaliczana jest do trudniejszych zadań konserwatorskich. Stosowane rozwiązania konstrukcyjne i ciesielskie w XV wieku i późniejszych latach zostały zapomniane przez współczesnych architektów - konserwatorów i brygady ciesielskie. Wykonane prace, które zaliczyć można do rekonstrukcyjnych, w kościele w Domaradzu, dowodzą, że przed przystąpieniem do prac konserwatorskich obiektów zabytkowych, należy wykonywać specjalistyczne badania mykologiczne i studia architektoniczno-konserwatorskie. Dopiero wyniki badań, dają podstawę do formułowania zaleceń konserwatorskich. Przyjęty tok postępowania w kościele, oparty został na metodzie zachowania nawarstwień kulturowych, oryginalnych struktur materiałowych i systemu połączeń ciesielskich. Kolejne etapy prac konserwatorskich, począwszy od wymiany belek podwalinowych, po wzmocnienie konstrukcyjne więźby dachowej, prowadzono po wykonaniu wnikliwych analiz stanu zachowania tychże elementów. W trakcie prac odsłonięto fragmenty wcześniejszych form konstrukcyjnych i polichromii. Odkryta belka, będąca pozostałością tzw. sobót została wyeksponowana, z myślą, ukazania śladów historycznych form architektonicznych obiektu. Metoda ta, jest powszechnie stosowana w postępowaniach konserwatorskich.
\end{abstract}

Słowa kluczowe: restauracja, rekonstrukcja, remont, przebudowa, wartość zabytkowa, polichromia

\section{Wprowadzenie}

Na przełomie XIX i XX wieku nastąpiła zmiana poglądów związana z konserwacją zabytków. Na Międzynarodowych Konferencjach wyznaczano kierunki i zasady postępowań konserwatorskich. Karta Krakowska 2000, która została uchwalona na Międzynarodowej Konferencji, wprowadziła szereg no-

\footnotetext{
1 Autor do korespondencji / corresponding author: Marek Gosztyła, Politechnika Rzeszowska, 35-959 Rzeszów, al. Powstańców Warszawy 12, tel. + 4817865 1939, gosztyla@prz.edu.pl

${ }^{2}$ Łukasz Gołda, lukaszgolda@onet.pl
} 
woczesnych metod ochrony i konserwacji zabytków. Zmieniające się narzędzia prawne i praktyka konserwatorska pozwalają na prowadzenie prac $\mathrm{z}$ rozumieniem istoty konstrukcji zabytków. ${ }^{3}$

Jednym z takich obiektów jest zabytkowy drewniany kościół w Domaradzu. ${ }^{4}$ Brak dokładnych materiałów archiwalnych związanych z powstaniem parafii oraz skali przekształceń świątyni w II poł. XIX w. znacznie utrudnia datowanie świątyni. Pierwsza wzmianka o istnieniu w tym miejscu kościoła pochodzi z 1359 r. Z kolei akt lokacyjny Nowego Domaradza z 1425 r. na prawie magdeburskim informuje, że jego mieszkańcy należą do już istniejącej parafii w Domaradzu. Analiza porównawcza obiektu z XV-wiecznymi kościołami w Bliznem i Golcowej, szczególnie bryły i detali architektonicznych, pozwala określić czas budowy kościoła na II połowę XV w. Podanie dokładniejszej daty stanie się możliwym po przeprowadzeniu badań dendrochronologicznych. Z 1542 r. pochodzi zapis o konsekracji kościoła św. Piotra i Pawła przez biskupa przemyskiego Stanisława Tarło. W 1545 r. miało miejsce wznowienie fundacji świątyni przez biskupa Jana Dziaduskiego. W XVII w. świątynia została otoczona sobotami, dobudowano wieże i ufundowano nowe wyposażenie. $\mathrm{W}$ trakcie dwóch remontów w XVIII w. położono kamienną posadzkę, wykonano prospekt organowy (1719 r.) oraz wymieniono stolarkę okienna i drzwiową (1756 r.). Jak wyglądała świątynia $\mathrm{w}$ tym czasie, dowiadujemy się z wizytacji biskupa Wacława H. Sierakowskiego z 1745 r. Kościół uległ znacznej przebudowie w 1878 r. za probostwa ks. Jana Bielenia. Przedłużono nawę w kierunku zachodnim, obniżono strop likwidując zaskrzynienia, a ściany prezbiterium wyrównano do poziomu ścian nawy. Jednoprzestrzenne wnętrze korpusu podzielono na trzy nawy, podpierające strop dwiema parami drewnianych słupów. W 1887 r. kościół ozdobiono nową, eklektyczną polichromią, której autorem był prawdopodobnie proboszcz Jan Bieleń. W 1906 w trakcie kolejnej przebudowy za proboszcza Michała Nowakiewicza rozebrano soboty, wzniesiono wieżyczkę na sygnaturkę oraz dobudowano kruchty. W 1936 r. proboszcz Michał Tuleja zdecydował się na zmianę pokrycia kościoła $\mathrm{z}$ gontu na blachę oraz wzniósł nową, wolnostojącą dzwonnicę o wysokości $15 \mathrm{~m}$. Ostatni remont kościół miał miejsce w latach $60 \mathrm{XX}$ w. Od czasów wybudowania w pobliżu nowej świątyni kościół jest sporadycznie użytkowany. Budowla pomimo przekształceń zachowała czytelny układ średniowieczny i zalicza się do najstarszych drewnianych kościołów w Polsce. Świątynia orientowana, o konstrukcji zrębowej z drewna modrzewiowego stoi na kamiennej podmurówce, o ścianach wzmocnionych lisicami i pokryta jest gontem jodłowym. Kruchty konstrukcji słupowej, ściany mają szalowane deskami w układzie pionowym z listwowaniem. Na zewnętrznej

\footnotetext{
${ }^{3}$ Gosztyła M., Pasztor P., Konserwacja i ochrona zabytków architektury, Wydanie II, Rzeszów 2013, s. 85-86.

${ }^{4}$ Miejscowość w woj. Podkarpackim, powiat brzozowski, gmina Domaradz.
} 
ścianie prezbiterium (od wschodu) znajduje się rzeźbiony krucyfiks (XVII w.). ${ }^{5}$ Prezbiterium na rzucie prostokąta, zamknięte jest trójboczną apsydą. Nawa szersza, na rzucie wydłużonego prostokąta (niegdyś kwadratowa) połączona jest z dwiema prostokątnymi kruchtami od zachodu i południa. Prezbiterium i nawa równej wysokości, nakryte jednokalenicowym, dwuspadowym dachem (od wschodu trójpołaciowym, od zachodu zamkniętym trójkątnym szczytem). $\mathrm{Na}$ szczycie kalenicy dachu wznosi się wieżyczka na sygnaturkę z latarnią. Zwieńczona jest ona hełmem w kształcie graniastosłupa. Kruchty pokryte zostały dachem dwuspadowym, zakrystia zaś - pulpitowym.

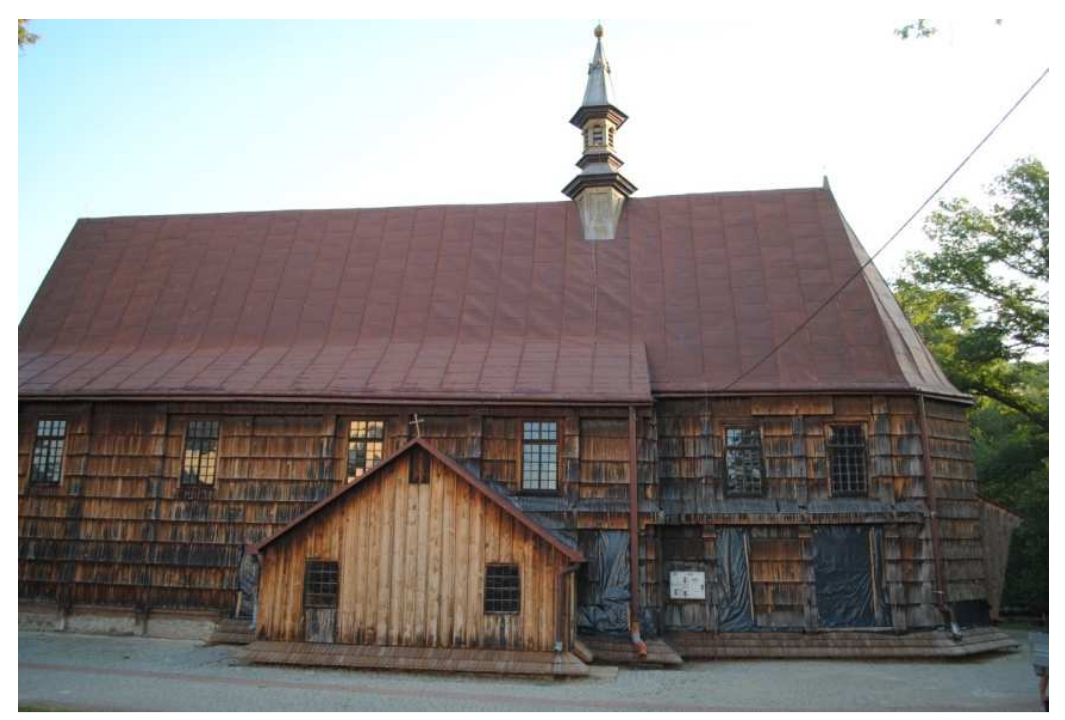

Rys. 1. Widok ogólny kościoła, strona południowa, 2012, fot. Ł. Gołda

Fig. 1. General view of the church, southern side, photo Ł. Gołda

W postępowaniu konserwatorskim obejmującym remont obiektu o wartości historycznej wykorzystuje się metodę: inżynierską, w której stosuje się współczesne technologie i materiały, oraz ciesielską, której celem jest odtworzenie danego elementu zachowując pierwotny kształt, materiał. Za stosowaniem metod ciesielskich w pracach budowlano - konserwatorskich przemawia celowość oddzielenia tradycji, historii od współczesnych technologii. ${ }^{6}$ Zabytkowy drewniany kościół w Domaradzu, ze względu na zły stan techniczny, wymagał wykonania specjalistycznego projektu architektoniczno - budowlanego. Inwestor ${ }^{7}$

\footnotetext{
${ }^{5}$ Zieliński K., Leksykon Drewnianej Architektury Sakralnej Podkarpacia, Tom I, Pro Carpatia, Rzeszów 2011, s. 62-63

${ }^{6}$ Bajon - Romańska M., Jak budowano drewniane kościoły w średniowiecznej Małopolsce, Dolnośląskie Wydawnictwo Edukacyjne, Wrocław 2008, s. 9-10

${ }^{7}$ Parafia rzymskokatolicka pw. MBNP w Domaradzu
} 
przedstawił odważną wizję przywrócenia kształtu świątyni z XVII w. Koncepcja, która zakładała odtworzenie pierwotnego wyglądu kościoła odbiegała od współczesnych pryncypiów konserwatorskich, a wykonanie takiej próby skutkowałoby nieodwracalnym zniszczeniem zachowanej konstrukcji. Rekonstrukcja kościoła z XVII w. polegająca na odtworzeniu sobót, skróceniu nawy i scalenia wolnostojącej dzwonnicy do strony zachodniej kościoła tworzyłaby domniemanie historyczne. Przyjęte podejście konserwatorskie skupiło się na rozsądnym rozwiązaniu, gdyż wykonano remont obiektu zachowując jego kunsztowne nawarstwienia $\mathrm{z}$ poszanowaniem historii świątyni. Zaplanowane prace restauratorskie polegały na remoncie konstrukcji i przywróceniu pierwotnego pokrycia kościoła, jakim był gont. Pierwszym etapem prac było zapewnienie stabilizacji posadowienia.

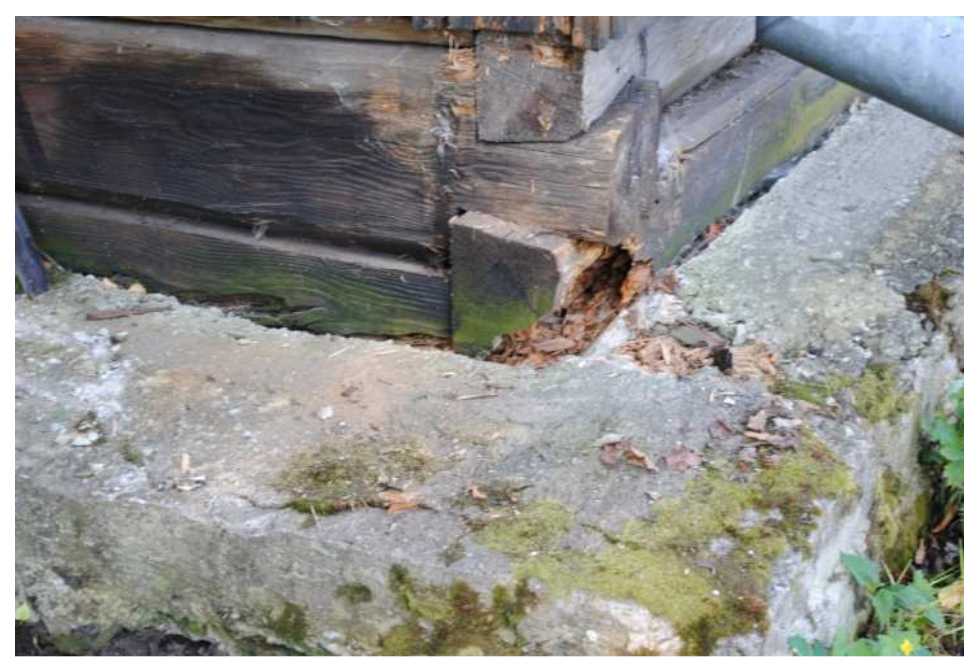

Rys. 2. Widok belek podwalinowych, strona wschodnia, 2012, fot. Ł. Gołda

Fig. 2. View of ground beams, eastern side, photo $Ł$. Gołda

Należy podkreślić, że wieniec belek podwalinowych jest elementem konstrukcyjnym każdego obiektu drewnianego najniżej położonym i narażony jest na zawilgocenie, co może skutkować pojawieniem się korozji biologicznej.

Niestabilność belek podwalinowych również może powodować osiadanie oraz niepożądane spękania konstrukcji. W większości obiektów z XV w. istnieje małe prawdopodobieństwo zachowania się pierwotnego materiału, z którego zostały wykonane belki posadowienia. Tak też było z podwalinami kościoła w Domaradzu.

Belki podwaliowe połączone w narożach na ,jaskółczy ogon" wykazywały rozluźnienia i znaczny stopień korozji biologicznej. Przyjęta metoda budowlano - konserwatorska polegała na wymianie zniszczonych belek, całego wieńca wraz z przemurowaniem podmurówki kamiennej z wykorzystaniem odzyskanego 
materiału. Wykonanie takiego zakresu prac wymagało dużej precyzji i zachowania bezpieczeństwa. Posłużono się poprawnie wykonanym stemplowaniem konstrukcji. Pomimo, że całkowita wymiana belek podwali nowych, nie jest podejściem w pełni konserwatorskim z uwagi na wprowadzanie zupełnie nowej struktury materiału, która nie ma wartości oryginalnej, to w tym przypadku, była konieczna i zrozumiała pod względem bezpieczeństwa konstrukcji. Nowe elementy tj. belki wykonano $\mathrm{z}$ zachowaniem pierwotnych przekrojów, gatunku materiału, sposobu łączenia i obróbki ciesielskiej, a izolację poziomą położono tradycyjnymi metodami (papa na lepiku).

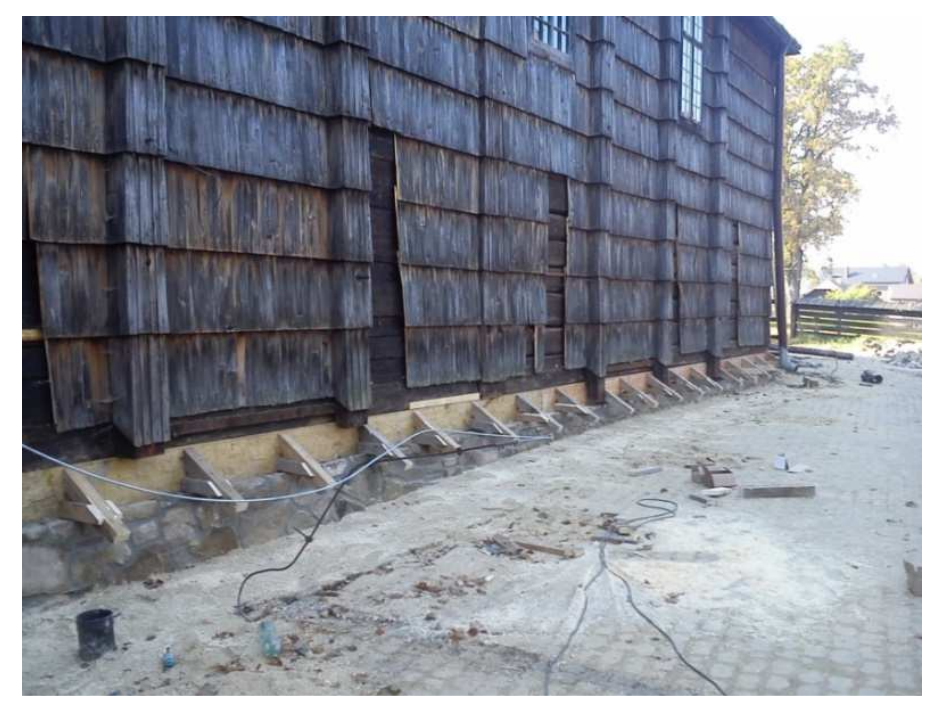

Rys. 3. Wymieniona belka podwalinowa z przemurowaną podmurówką kamienną oraz konstrukcją pod fartuch ochronny, strona północna, 2012, fot. Ł. Gołda

Fig. 3. Replaced ground beam with the rebuilt stone wall base and score apron structure, north side, photo . Gołda

Średniowieczne konstrukcje dachowe obiektów zabytkowych do dnia dzisiejszego budzą ogromne zainteresowanie wśród badaczy. Przyjmowane z nadmiarem przekroje pozwoliły przetrwać więźbą kilka wieków i służą po obecny czas. Konstrukcje wykonywane były na ziemi, a montowane na oczepie według znaków ciesielskich. Przykładem jest konstrukcja więźby dachowej na zabytkowym kościele w Domaradzu, o czym świadczy szereg znaków na istniejącej konstrukcji.

Drugi etap prac obejmował remont konstrukcji więźby dachowej i miał za zadanie przywrócić pierwotne pokrycia gontowe. Odtworzenie pierwotnej konstrukcji storczykowej, jaka występuje w kościołach z tego okresu było niemożliwe, ze względu na znaczny stopień zmian dachu, po modernizacjach obiektu. 
Prace budowlano - konserwatorskie więźby dachowej były wykonane z pozostawieniem obecnej konstrukcji. Remont polegał na wymianie zniszczonych elementów z zachowaniem połączeń ciesielskich i nie naruszał statyki dachu. Wymieniane fragmentami elementy scalane były z istniejącymi lub dawane nowe, w przypadku znacznego zniszczenia. W przypadku wymiany całego elementu i scalenia $\mathrm{z}$ konstrukcją zastosowano i odtworzono pierwotne zacięcia ciesielskie na tzw. ,płetwę” a elementy łączono na kołki.

Bezpodstawne stosowanie łączników stalowych jest błędem w podejściu konserwatorskim, ale może być dopuszczalne w przypadkach, kiedy element konstrukcyjny nie podlega w całości wymianie, lecz należy wykonać uzupełnienie materiału o tzw. ,protezę" i scalić z pierwotnym elementem nie pozbawiając stateczności konstrukcji.

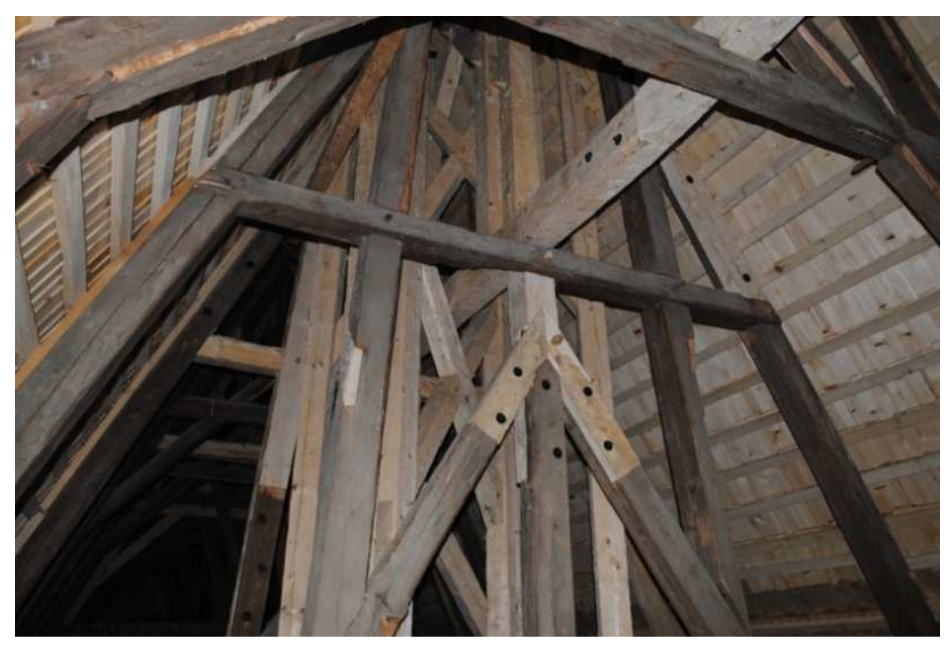

Rys. 4. Widok scalenia protezy z pierwotnym materiałem za pomocą kutych śrub, 2014, fot. Ł. Gołda

Fig. 4. View of merging of the prosthesis with the primary material by means of forged bolts, 2014, photo Ł. Gołda

Takie rozwiązanie przyjęto przy wzmacnianiu więźby dachowej. Dodatkowym zabezpieczeniem konstrukcji jest jej oczyszczenie i impregnacja, która chroni materiał przed korozją biologiczną.

W trakcie remontu konstrukcji zabytkowego kościoła w Domaradzu zinwentaryzowano historyczne łączenia elementów. 


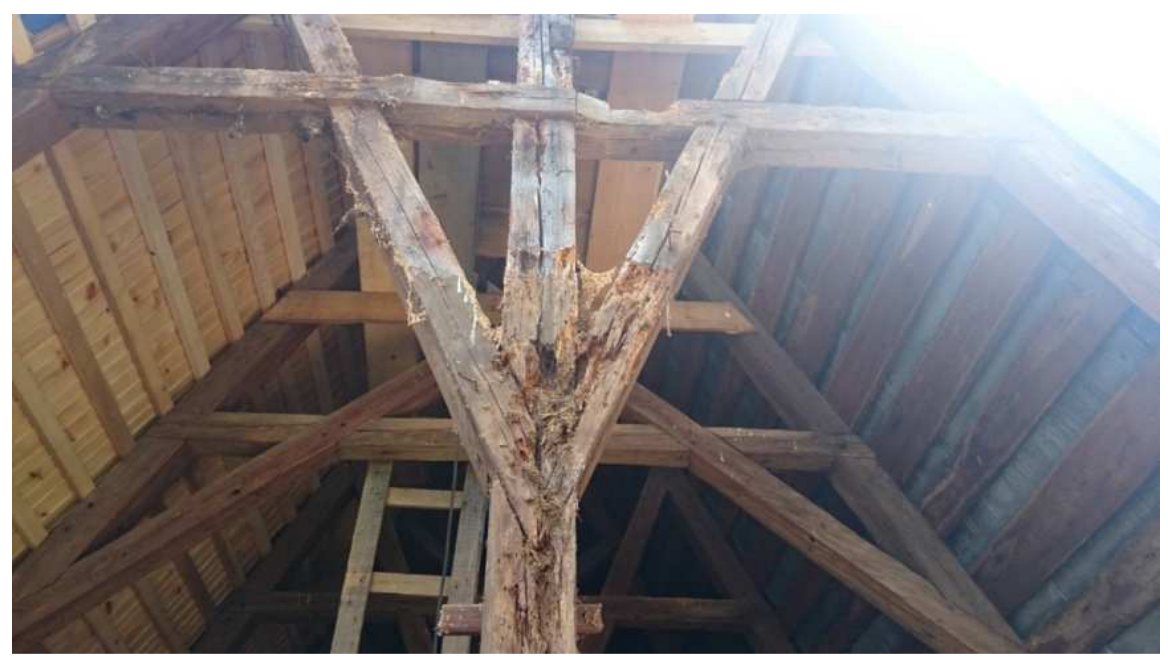

Rys. 5. Widok zniszczonego wiązara dachowego ściany szczytowej, strona zachodnia, 2014, fot. Ł. Gołda

Fig. 5. View of the damaged roof truss of the end wall, western side, 2014, photo $€$. Gołda

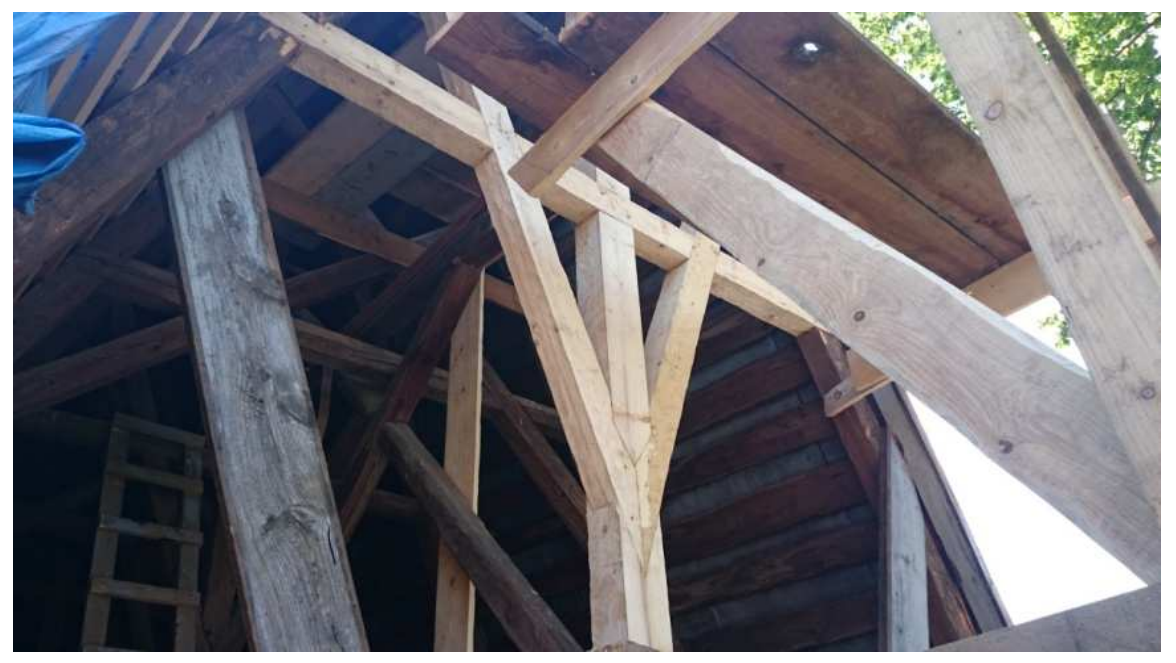

Rys. 6. Nowy wiązar dachowy ściany szczytowej, strona zachodnia, 2014, fot. Ł. Gołda

Fig. 6. New roof truss of the end wall, western side, 2014, photo Ł. Gołda 


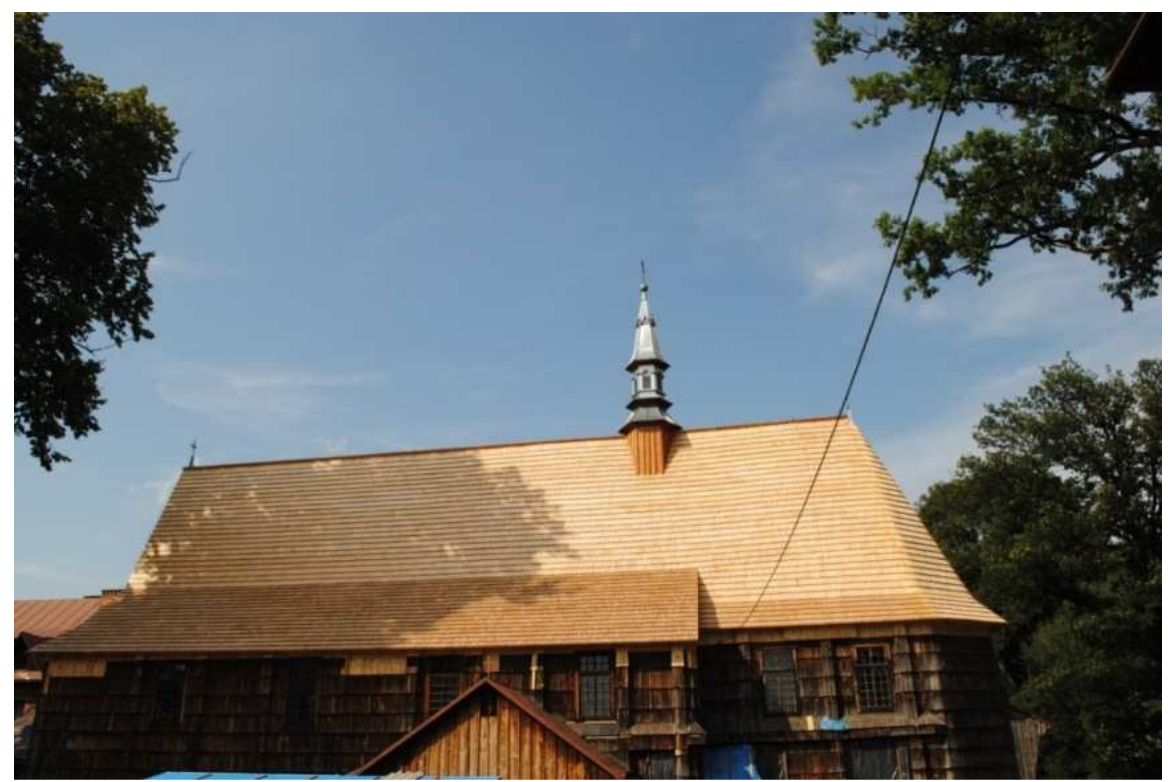

Rys. 7. Widok nowego pokrycia gontowego więźby dachowej z oblachowaniem sygnaturki, 2014, fot. Ł. Gołda

Fig. 7. View of new shingled roof framework with the flashing of spirelet, 2014, photo Ł. Gołda

Podjęta została decyzja o odtworzenie pierwotnego pokrycia dachu, jakim był gont. Przywrócenie historycznego pokrycia miało uzasadnienie wynikające $\mathrm{z}$ dokumentacji archiwalnej.

Końcowy etap prac zakładał wymianę opierzenia ścian świątyni. Ściany zrębowe pokryte zostały gontem jodłowym na pojedynczym kryciu, a kruchty pionowym deskowaniem $\mathrm{z}$ olistwowaniem. W części prezbiterium zachowała się podokienna belka wsporcza, która jest jedynym potwierdzeniem istnienia sobót. Odtworzenie pierwotnego wyglądu sobót było niemożliwe ze względu na brak zachowanej dokumentacji archiwalnej. Pozostawiając fragment konstrukcji świadczący o istnieniu sobót zastosowano tradycyjne podejście konserwatorskie polegające na uwidocznieniu tzw. „świadka”.

W kościele odnotowano nawarstwienia kulturowe: znaki ciesielskie, malowidła, które stanowią cenną wartość historyczną i dydaktyczną. Odkryto fragmenty zaskrzynienia z pierwotną polichromią malowaną bezpośrednio na deskach, co może być dowodem na XV wieczne pochodzenie kościoła. 


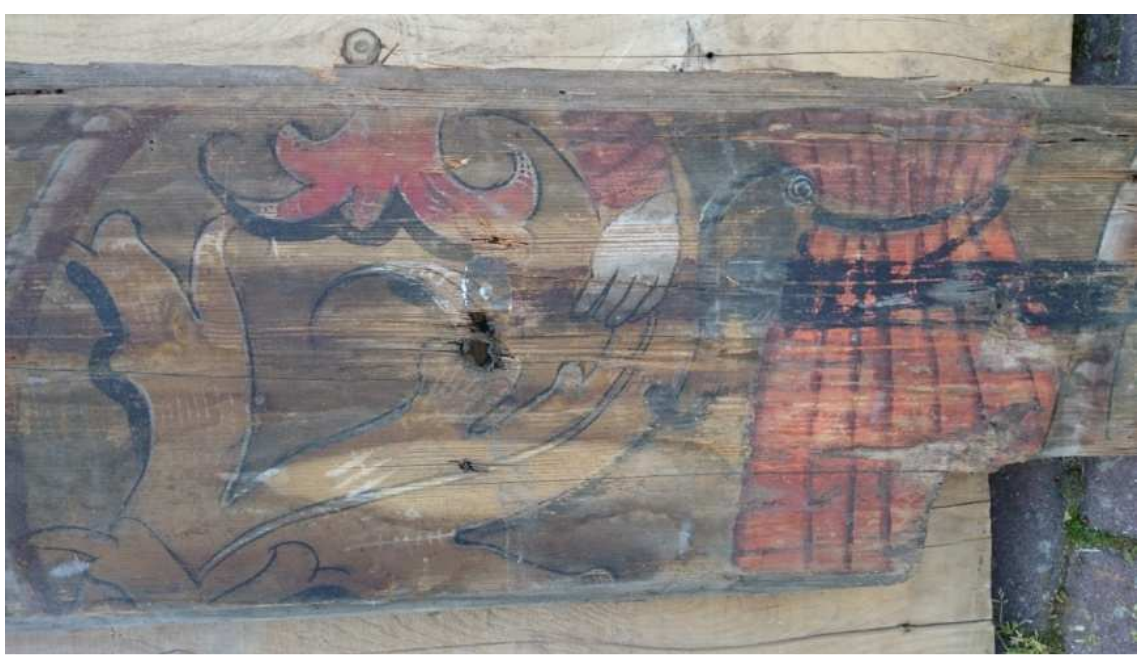

Rys. 8. Fragment pierwotnej polichromii na zaskrzypieniu, 2013, fot. Ł. Gołda

Fig. 8. A fragment of the original polychrome on connecting fragments, 2013, photo Ł. Gołda

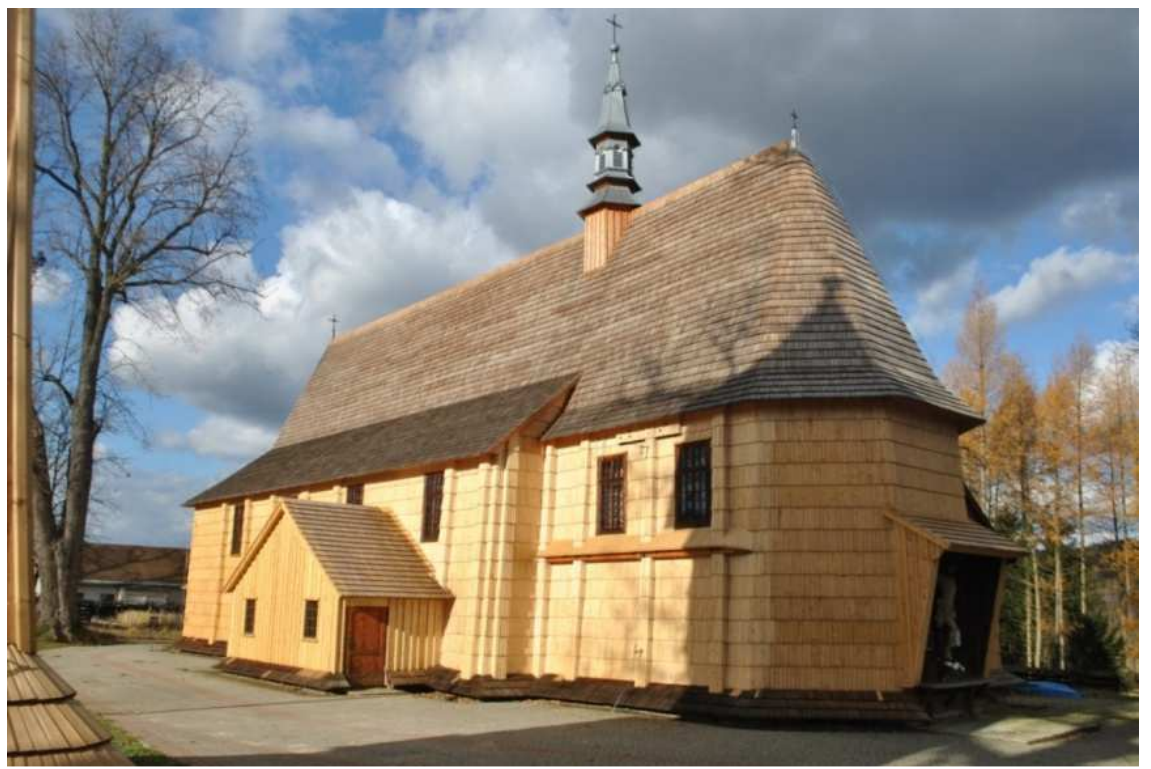

Rys. 9. Widok kościoła po remoncie, strona południowo - wschodnia, 2015, fot. Ł. Gołda Fig. 9. View of the church after the repair, south - eastern side, photo Ł. Gołda 


\title{
Podsumowanie
}

Wykonywanie prac remontowych na obiekcie zabytkowym jest zadaniem zaliczanym do trudnych i niesie ze sobą dużą odpowiedzialność zawodową. Przystępując do tego typu prac należy umieć docenić wartości materialne jak $\mathrm{i}$ historyczne obiektu. Istotną rzeczą jest dobre przygotowanie się do prac konserwatorskich, polegające na zapoznaniu się i zrozumieniu stanu technicznego zabytku, ponieważ każde nieprzemyślane rozwiązanie skutkować będzie nieodwracalnymi zmianami i utratą wartości kulturowych. W przypadku nowych odsłonięć nawarstwień kulturowych, każdorazowo powinno się opracować projekt ekspozycji lub przykrycia uznanych wartości dziedzictwa kulturalnego.

\section{Literatura}

[1]Bajon- Romańska M., Jak budowano drewniane kościoły w średniowiecznej Małopolsce, Dolnośląskie Wydawnictwo Edukacyjne, Wrocław 2008.

[2] Gosztyła M., Pasztor P., Konserwacja i ochrona zabytków architektury, Wydanie II, Rzeszów 2013.

[3]Zieliński K., Leksykon Drewnianej Architektury Sakralnej Podkarpacia, Tom I, Pro Carpatia, Rzeszów 2011.

\section{BUILDING - CONSERVATION ISSUES OF THE WOODEN STRUCTU-RES OF HISTORIC BUILDINGS ON THE EXAMPLE OF THE CHURCH UNDER THE INVOCATION OF ST. NICHOLAS BISHOP IN DOMARADZ}

\begin{abstract}
S u m m a r y
The issue of conducting the revaluation works of wooden historic buildings is considered to be the most difficult conservation task. The construction and carpentry solutions used in the fifteenth century and later years have been forgotten by modern architects - conservators and carpentry teams. The works done, which can be considered as the reconstruction works in the church in Domaradz, prove that prior to conservation works of historic buildings, the specialist mycological testing as well as architectural and conservation studies should be performed. Only the results of studies provide a basis for formulating the conservation recommendations. The adopted course of proceedings in the church was based on a method of preserving cultural strata, original material structures and system of carpentry joints. The successive stages of restoration works, starting from the replacement of ground beams, ending up with the structural reinforcement of the roof framework, was carried out after a thorough evaluation of the state of preservation of these elements. During the works the fragments of earlier structural forms and polychrome were uncovered. The uncovered beam, which is a remnant of the so-called archades, has been exposed, in order to demonstrate the traces of historical architectural forms of the object. This method is commonly used in the conservation practice.
\end{abstract}

Keywords: restaurant, reconstruction, repair, rebuilding, historic value, polychrome

DOI:10.7862/rb.2016.259

Przestano do redakcji: $30.06 .2016 r$.

Przyjęto do druku: 20.12.2016 r. 